\title{
Problems of Ensuring Innovative Development of Credit Activities of Commercial Banks and Ways of their Solution
}

\author{
Azimova Shakhnoza Samukdjanovna
}

\begin{abstract}
This article analyzes the problems of credit activities of commercial banks in Uzbekistan and offers recommendations for their elimination.
\end{abstract}

Keywords : bad loans, innovation, overdraft, credit risk, diversification, investment, assets, reserve contributions, forfeiting, ekskro-accounts, online lending, POS-lending.

\section{INTRODUCTION}

$\mathrm{T}_{\mathrm{h}}$ he Strategy for Action on Five Priority Directions of the Development of the Republic of Uzbekistan for 2017-2021 specifically states that deepening the reform and ensuring stability of the banking system, strengthening their financial stability and reliability is one of the prerequisites for further strengthening macroeconomic stability and maintaining high rates of economic growth [1].

In turn, strengthening the financial stability and reliability of commercial banks directly depends on the level of quantitative and qualitative development of credit activities of commercial banks. This is because loans occupy a relatively large proportion of the total assets of commercial banks. Therefore, the bulk of the income of commercial banks is interest income on loans, and the deterioration in the quality of the loan portfolio will lead to a decrease in the bank's liquidity level.

However, at present, there are urgent problems associated with the development of credit activities of commercial banks in Uzbekistan. In particular, there are no such forms of lending to legal entities as overdraft, contractor, forfaiting. In addition, in large commercial banks of Uzbekistan, the level of reserve deductions intended to cover losses on loans exceeds the normative level of this indicator.

The solution of urgent problems associated with the development of credit activities of domestic banks, necessitates the innovative development of credit activities of banks through the introduction of innovative credit products.

\section{A REVIEW OF THE LITERATURE ON THE TOPIC}

According to A. Andreev, banking innovations are a special case of innovations of the entire financial sector of the economy. Modification is an improvement, modification.
With regard to financial innovation, this is the creation of improved products, services instead of existing, but already outdated. For example, the introduction of express loans in commercial banks or consumer cooperatives. This type of loan meets the same needs as a classic loan. However, it has slightly different conditions: the time for approval of the application and the required package of documents is much less, but the percentage on the loan is much larger. In fact, this type of loan is an improvement of the classic loan [2].

According to A. Mishchenko, the priority direction of state regulation of credit activities of commercial banks is to create the necessary institutional conditions for the development of such areas as investment, consumer and mortgage lending.

At the same time, measures of state influence that can create the necessary incentives for the development of these types of bank lending are the creation of an effective system for regulating bank risks arising from lending to investment projects and their redistribution among all participants in the innovative lending system, including government agencies; refinancing commercial banks, introducing transparent lending schemes, as well as creating a system of state guarantees that reduce the risk of long-term loans through the use of financial resources raised on a short-term basis; development and implementation of professional lending standards; development of the mortgage lending infrastructure and increasing its reliability [3].

The results of the research by A. Vorobyeva showed that, due to the specifics of credit technologies, all innovations in this field are doomed to be improving and modifying in nature. Fundamental innovations in bank lending, involving the implementation of a completely new idea, business concept, and the emergence of new functional qualities of a bank loan as a product, may arise at the junction of the areas of credit, settlement, and customer information services by implementing the provision of complex financial products. It is here that one should expect the appearance of any significant innovative products [4].

\section{ANALYSIS AND RESULTS}

Loan arrears are one of the urgent problems in the development of the country's commercial banks. Therefore, the Central Bank is entrusted with the task of monitoring the process of collecting bad loans from commercial banks (pic. 1).

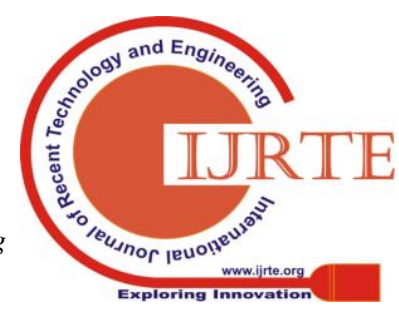




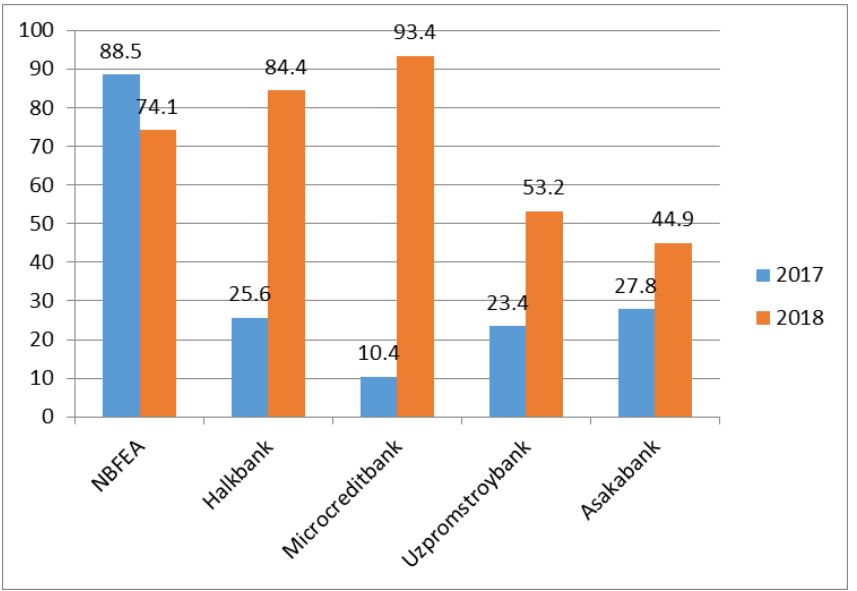

Figure No.1:The requirement for commercial banks of the Republic of Uzbekistan to recover problem loans[5]

As can be seen from the data pic. 1 in accordance with the Decree of the President of the Republic of Uzbekistan PD-3270 dated september 12, 2017 "On measures to further develop and improve the stability of the banking system of the republic," a specific requirement was put to commercial banks to recover problem loans.

Table 1:The structure of loans of commercial banks of Uzbekistan by maturity[3]

\begin{tabular}{|c|c|c|c|c|c|}
\hline Indicators & 2014 & 2015 & 2016 & 2017 & 2018 \\
\hline Loans - total. billion soums & 32161 & 42685 & 52596 & 110572 & 167391 \\
\hline Short-term loans, billion soums & 4403 & 4193 & 4244 & 4753 & 8663 \\
\hline $\begin{array}{l}\text { The share of short-term loans in the total } \\
\text { volume of loans, } \%\end{array}$ & 13,7 & 9,8 & 8,1 & 4,3 & 5,2 \\
\hline Long-term loans, billion sums & 27758 & 38492 & 48367 & 105819 & 158728 \\
\hline $\begin{array}{l}\text { The share of long-term loans in the total } \\
\text { volume of loans, } \%\end{array}$ & 86,3 & 90,2 & 91,9 & 95,7 & 94,8 \\
\hline
\end{tabular}

As of january 1, 2019, the volume of bad loans in the structure of the total loan portfolio of commercial banks amounted to 2.6 trillion. soums, and in 2018 increased by 351 billion soums or 16 percent. The share of bad loans in commercial banks in the total volume of credit investments decreased by 0.5 percent and amounted to 1.5 percent as of january 1, 2019.

In our opinion, one of the main reasons for the formation of bad loans in large volumes is the low level of diversification of the loan portfolio of domestic commercial banks.

As can be seen from table 1, long-term loans occupy a very large proportion in the total volume of loans of commercial banks in Uzbekistan. This is due to the wide involvement of commercial banks in the process of financing state programs.

There is also a deterioration in the loan portfolio of banks as a result of an increase in the volume of policy loans. International practice shows that a large number of preferential policy loans will increase the cost of lending to other economic entities and reduce the quality of the banks' loan portfolio.

It should be noted the absolute underdevelopment of investment operations of domestic commercial banks and occupy only $1 \%$ (table 2). Loans are the main type of assets of commercial banks in Uzbekistan $(65,1 \%)$. This is due to the fact that, firstly, loans are considered by the state as one of the important sources of financing investments, and secondly, investment operations of commercial banks of the republic remain undeveloped.

In world banking practice, when diversifying the loan portfolio of commercial banks, first of all, the industry specificity of the loans granted is taken into account[6]. 
Table-II:Asset structure of commercial bucks in Uzbekistan[6]

\begin{tabular}{|l|c|c|c|c|c|c|}
\hline \multirow{2}{*}{ Asset structure } & \multicolumn{2}{|c|}{01.01 .2017} & \multicolumn{2}{c|}{01.01 .2018} & \multicolumn{2}{c|}{01.01 .2019} \\
\cline { 2 - 7 } & $\begin{array}{c}\text { billion } \\
\text { soums }\end{array}$ & $\begin{array}{c}\text { specific } \\
\text { weight }\end{array}$ & $\begin{array}{c}\text { billion } \\
\text { soums }\end{array}$ & $\begin{array}{c}\text { specific } \\
\text { weight }\end{array}$ & $\begin{array}{c}\text { billion } \\
\text { soums }\end{array}$ & $\begin{array}{c}\text { specific } \\
\text { weight }\end{array}$ \\
\hline Cash & 1336 & $1,6 \%$ & 4841 & $2,9 \%$ & 5269 & $2,5 \%$ \\
\hline Funds at the Central Bank & 11958 & $14,2 \%$ & 14909 & $9,0 \%$ & 11429 & $5,3 \%$ \\
\hline Funds in other resident banks & 4281 & $5,1 \%$ & 6713 & $4,0 \%$ & 6374 & $3,0 \%$ \\
\hline $\begin{array}{l}\text { Funds in other non-resident } \\
\text { banks }\end{array}$ & 6588 & $7,8 \%$ & 18347 & $11,0 \%$ & 13545 & $6,3 \%$ \\
\hline Securities Investments & 1492 & $1,8 \%$ & 1649 & $1,00 \%$ & 2277 & $1,1 \%$ \\
\hline $\begin{array}{l}\text { Customer financial instrument } \\
\text { liabilities }\end{array}$ & 1129 & $1,3 \%$ & 2466 & $1,5 \%$ & 1879 & $0,9 \%$ \\
\hline Loans & 52045 & $62,0 \%$ & 108467 & $65,1 \%$ & 164670 & $76,8 \%$ \\
\hline Fixed assets & 1794 & $2,1 \%$ & 2335 & $1,4 \%$ & 3488 & $1,6 \%$ \\
\hline Interest charges & 593 & $0,7 \%$ & 1413 & $0,8 \%$ & 2842 & $1,3 \%$ \\
\hline Other property of banks & 386 & $0,5 \%$ & 298 & $0,2 \%$ & 230 & $0,1 \%$ \\
\hline Other assets & 2474 & $2,9 \%$ & 5193 & $3,1 \%$ & 2416 & $1,1 \%$ \\
\hline Assets total & $\mathbf{8 4 0 7 5}$ & $\mathbf{1 0 0 , 0 \%}$ & $\mathbf{1 6 6} \mathbf{6 3 2}$ & $\mathbf{1 0 0 , 0 \%}$ & $\mathbf{2 1 4 4 2 0}$ & $\mathbf{1 0 0 , 0 \%}$ \\
\hline
\end{tabular}

There are also such problems as there are no such forms of lending to legal entities as overdraft, contractor, and forfaiting. In addition, in large commercial banks of
Uzbekistan, the level of reserve deductions intended to cover losses on loans exceeds the normative level of this indicator (table

Table-III:The level of reserve deductions intended to cover losses on loans in relation to gross assets in Asakabank and Turonbank[7]

\begin{tabular}{|c|c|c|c|c|c|}
\hline Banks & 2014 y. & 2015 y. & 2016 y. & 2017 y. & 2018 y. \\
\hline Asakabank & 0,3 & 0,7 & 1,9 & 1,7 & 2,1 \\
\hline Turonbank & 0,6 & 0,7 & 0,4 & 0,1 & 1,7 \\
\hline
\end{tabular}

It is also necessary to note the adaptive nature of the innovative development of credit activities of domestic banks.
For example, overdraft loans for individuals are very low (pic.2).

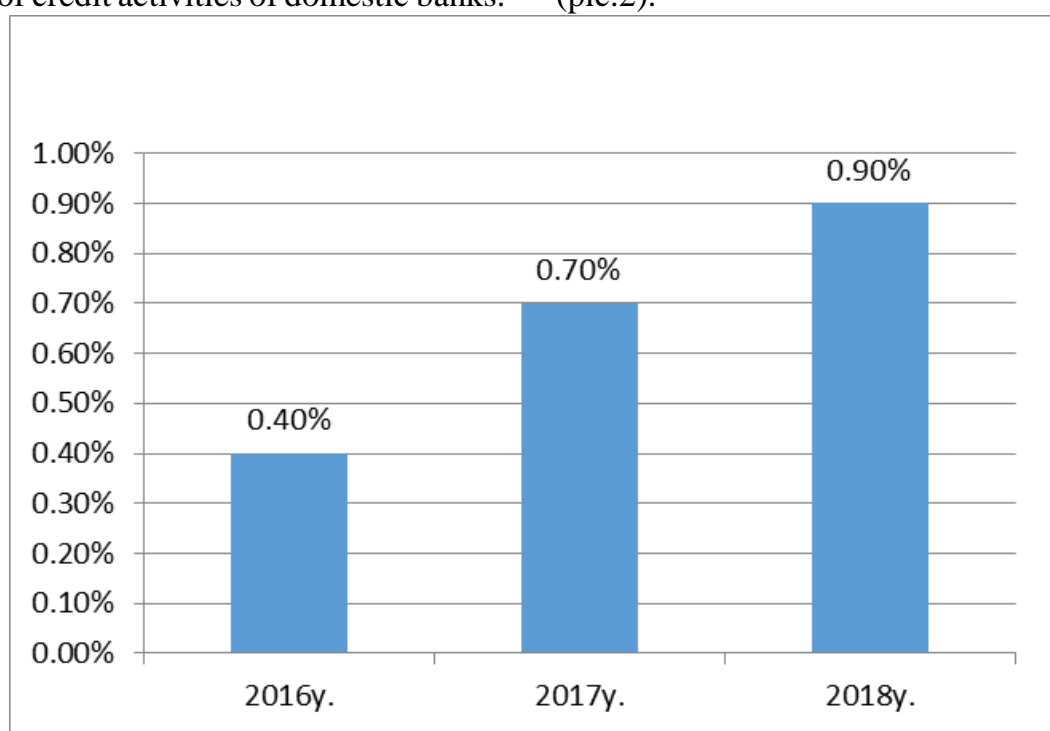

Figure No.2:Separate all overdraft loans in the total volume of loans provided to individuals[8] 
commercial banks of Uzbekistan, from 16 to $38 \%$ per annum (pic.3)

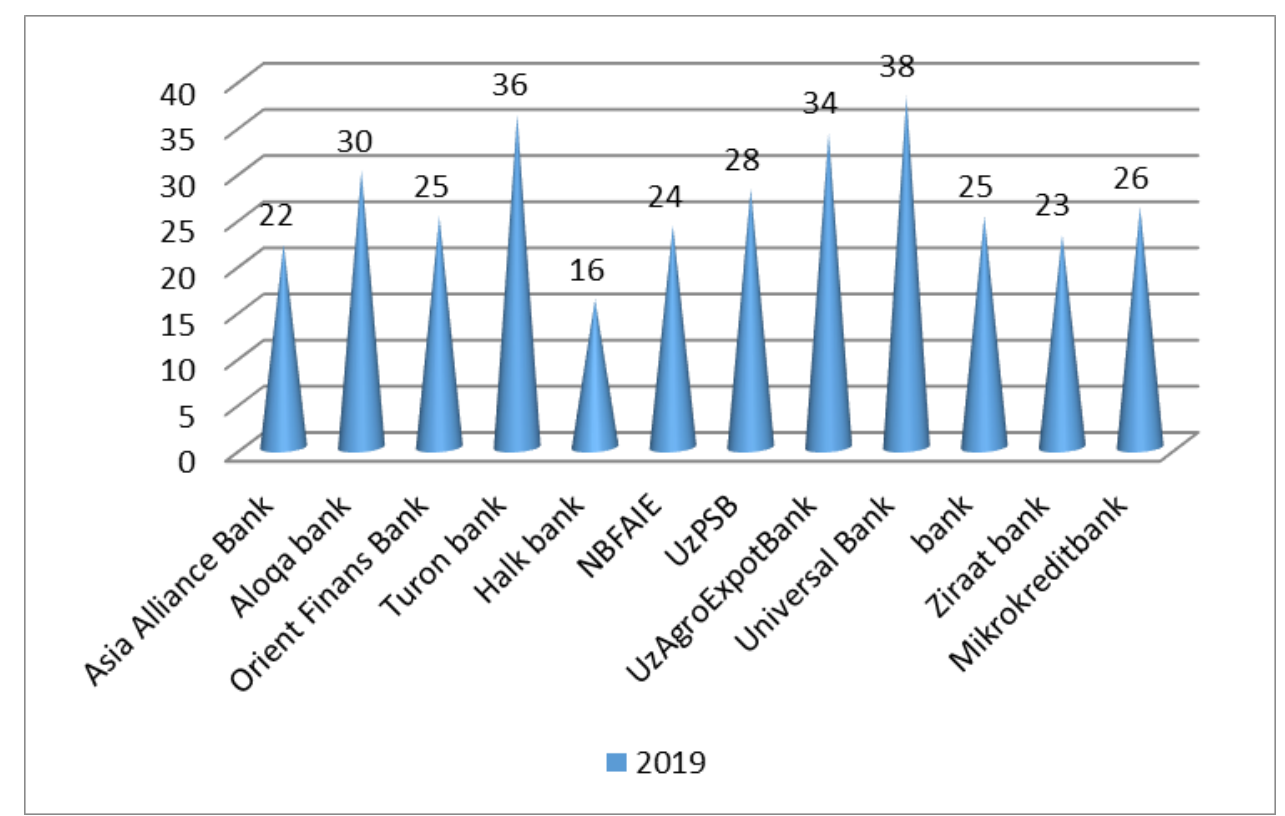

Figure .3: Interest rates on overdraft to individuals in commercial banks of Uzbekistan,\% [9]

Unlike foreign banks, where overdraft is also provided to legal entities, this practice is absent in our banks. For example, in Sberbank of Russia, overdraft lending is carried out on the following conditions. The cost of overdraft debit card services for individuals at Sberbank is $18 \%$ per annum for ruble cards. The commission in dollars and euros is $16 \%$ per annum. Moreover, if you exceed the limit of your expenses, in this case the interest rate will immediately be increased to $36 \%$ per annum in rubles. Therefore, with the use of cash on the card, you should be careful. Interest will accrue on the amount that was actually spent on overdraft. If there are not enough funds on your card on the day of writing off payments, it is better to take care of its timely replenishment. Legal entities often use overdraft services from Sberbank when there is not enough money in the current account of an individual entrepreneur or legal entity to settle accounts with customers or pay for services. The bank allows overdraft in the event that a constant flow of funds is observed in the current account. As soon as the money is returned to the entrepreneur's account, the bank automatically takes the amount of funds issued to the client, as well as the interest established for this service. A legal entity can conclude an overdraft agreement directly with the bank.

In 2018, Sberbank entered the POS lending market with the new product "Purchases on credit". To develop the product line, a credit marketplace was launched.

"Buy with Sberbank" is a service for applying for a POS loan for goods on the websites of Sberbank's partners. In this case, the application, the consideration of the request and the signing of documents are carried out online and do not imply the participation of bank employees or partners. The advantage of the product is the technology that provides a quick and completely paperless loan processing process.

A significant event of 2018 for Sberbank was the launch of the "Credit in 7 minutes" service, which is an online loan for large businesses that has no analogues in the country.

"By product. Credit in 7 minutes" a decision on a loan to a large corporate borrower is made in just 7 minutes without requesting documents from the client. The loan can be obtained both by customers who already have existing or repaid loans at Sberbank, as well as customers who have not previously been credited to the bank, but who conduct settlement activities through accounts at Sberbank.

In 2018, the bank conducted a pilot on the use of machine learning in lending to major customers: alternative ML models of forecast cash flows were built for 12 companies in the trading and telecom industries. In 2019, the pilot will be expanded to 200 companies in the large / medium business segment. Thanks to automation, the term of working with the cash flow model within the transaction can be reduced from a few days to 4 hours.

Due to the specifics of credit technologies, all innovations in this area are doomed to be improving and modifying in nature. Fundamental innovations in bank lending, involving the implementation of a completely new idea, business concept, and the emergence of new functional qualities of a bank loan as a product, may arise at the junction of the areas of credit, settlement, and customer information services by implementing the provision of complex financial products. It is here that one should expect the appearance of any significant innovative products.

\section{CONCLUSIONS AND OFFERS}

Having studied the issues of innovative lending, we came to the following conclusions.

The benefits of overdraft include mainly:

1. Overdraft is not a targeted loan.

A loan for business development, a consumer loan, a home loan -

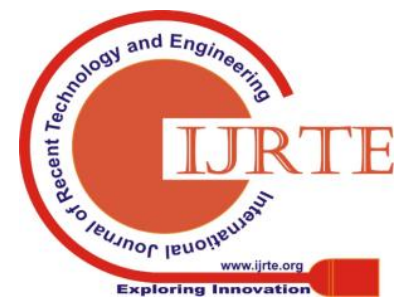


each of these loans has a distinct purpose.

When receiving an overdraft, the client is not limited in their ability to spend the amount received on anything. For example, if you take a loan from a bank for the purchase of household appliances, then if you, after applying for a loan, have looked at another TV model and in a different store, you will have to re-arrange the loan.

2. Overdraft is a revolving loan. This means that after you have repaid the overdraft debt, the limit on the card reopens. You do not need to get a new loan at the same time, there is no need for documentary delays. Using an overdraft, the main thing is to repay the debt during the time and then it will be possible to use this service for more than one year.

3. No deposit is required to receive an overdraft. This is a significant advantage over many types of loans.

4. Overdraft interest is accrued only on the amount used, and not on the entire limit. That is, if you have opened the overdraft service, but you temporarily do not use it, then interest is not accrued to you.

The disadvantages of overdraft include:

1. The most significant drawback of an overdraft is its high cost, since the interest rate is higher than for other loans. This is due to the fact that overdraft is considered a risky type of lending for the bank. Therefore, the bank has to insure the risk of default on money with a high interest rate.

2. Overdraft size is limited.

3. Another disadvantage is the complexity of the design of this banking service.

Most analysts argue that today the question of whether or not borrowers should resort to this type of lending should be decided separately and have an individual approach. If the client is confident in himself and is ready to bear debt obligations, knows how to plan his own budget well, and is also confident in the stability of current sources of income, then this service will be comfortable and will serve as a good complement to financial opportunities. Of course, those customers who do not have all this should be careful and not get into extra debt. Having drawn up an overdraft, you need to take care of regularly depositing or receiving money into your current account for monthly repayment of the debit balance in accordance with the terms of the contract.

In our opinion, in order to improve the lending activities of commercial bucks in Uzbekistan based on innovation, the following measures should be taken:

1. To improve the practice of lending to individuals, it is necessary:

* Firstly, to reduce credit risks by forming a reliable customer base from those individuals who already have bank accounts, to improve the methodological basis for assessing creditworthiness and testing procedures for employee qualifications.

* secondly, to improve credit technologies;

* thirdly, introduce new lending programs with highly liquid collateral.

2. It is necessary to expand the scope of using forms of lending by opening a credit line by increasing the liquidity level of commercial banks, by forming groups of customers with a high level of liquidity and solvency.

3 . It is necessary to create a condition for the integrated use of loan forms by ensuring standard levels of indicators characterizing the profitability and riskiness of loans.
4. It is necessary to increase the level of diversification of the loan portfolio of commercial banks by increasing the volume of innovative loans provided to individuals.

5. It is necessary to improve the structure of classified loans by applying innovative methods of credit risk management.

6. It is necessary to halve the rate of the required reserve of the Central Bank of the Republic of Uzbekistan for those commercial banks for which the share of innovative loan products exceeds $50 \%$ of the total amount of loan products.

The proposed recommendations to eliminate the above problems will contribute to the innovative development of credit activities of banks in Uzbekistan

\section{REFERENCES}

[1] Decree of the President of the Republic of Uzbekistan No. 4947 of february 7, 2017 «Strategy of action in five priority areas of the development of the Republic of Uzbekistan for 2017-2021». www.lex.uz

[2] Andreeva, A.V. The role of financial innovation in the development of the banking services market [Text] / A.V. Andreeva // Banking services. - 2010. - No. 6. - P.32.

[3] BAKHTISHODOVICH, BOBUR SOBIROV, et al. "The role of social media, user generated platforms and crowd sourcing in the development of tourism destinations." Journal of Hospitality Management and Tourism 6.4 (2015): 30-38.

[4] Sobirov, Bobur. "Innovative development of tourism in Uzbekistan." American Journal of Economics and Business Management 1.1 (2018): 60-74.

[5] Sobirov, Bobur. "The concept of the tourist economic zone. Case of Uzbekistan." World Scientific News 98 (2018): 34-45.

[6] Abdurakhmanov, K., Zokirova, N., Shakarov, Z., \& Sobirov, B. (2018). DIRECTIONS OF INNOVATIVE DEVELOPMENT OF UZBEKISTAN. National Academy of Managerial Staff of Culture and Arts Herald, (3).

[7] Mishchenko A.V. Lending activities of commercial banks in Russia: specifics of management and regulation. Diss. for a job. student Art. Ph.D. - Rostov - on - Don, 2013 .-P.15.

[8] Vorobyova I.S. Credit innovations in the banking sector (on the example of car loans) / Abstract. for a job. student step. Cand. econ. Sciences. Russian University of Economics G.V. Plekhanova, 2014 .$-30 \mathrm{p}$

[9] Decree of the President of the Republic of Uzbekistan PD-3270 dated september 12, 2017 "On measures to further develop and increase the stability of the banking system of the republic." www.lex.uz

[10] www.cbu.uz (Annual reports of Central Bank of the Republic of Uzbekistan)

[11] Bank Management Textbook. ed. prof. O.I. Lavrushin. - M . KNORUS. 2016 .-P. 275.

[12] Annual reports of Asakabank and Turonbank (www.asakabank.uz www.turonbank.uz)

[13] www.spot.uz

[14] Decree of the President of the Republic of Uzbekistan No. 3620 of March 23, 2018 "On additional measures to increase the availability of banking services". www.lex.uz

[15] Bank Management Textbook. ed. prof. O.I. Lavrushin. - M . KNORUS. 2016 .-768p.

[16] Allen F., Gale D. Comparing Financial Sestems. - Cambridge, Mass: MIT Press, 2000. - 519 p.

[17] Scott J.A., Dinkelberg W.C., Dennis W.J. Credit, Banks and Small Business - the New Century - Washington: NFIB Research Foundation, 2003. -96 p. 